\title{
Some Aspects of the Cloud Formation and Its Relation to the Heat and Moisture Supply from the Japan Sea Surface under a Weak Winter Monsoon Situation
}

\author{
By S. Matsumoto and K. Ninomiya \\ Meteorological Research Institute, Tokyo \\ (Manuscript received 6 December 1965)
}

\begin{abstract}
A high altitude aerial photographic cloud observation was made over the Japan Sea on January 20, 1965 when a comparatively weak monsoon covered the Japan Sea and her neighbourhood. Remarkable facts are that the cloud amount was closely related to the sea surface temperature, that the cloud height was almost uniformly about $2 \mathrm{~km}$ which coincides with the height of inversion observed downstream and that the size of convection system was also uniform.

Some quantitative discussions are tried on vapor, condensed water and heat budget under steady state assumption.
\end{abstract}

\section{Introduction}

Aerial photographic observations of clouds have recently been given more attention in many respects such as tropical meteorology, hurricane dynamics, mesometeorology as well as cloud dynamics. In order to study the air mass modification over the ocean and related effects on weather, the ovservations of cloud distribution and other characteristics would provide important informations (Riehl and Malkus, 1957 and 1958; Malkus, Ronne and Chaffee, 1961).

Clouds are the visible manifestation of convective activities which redistribute the heat and moisture in the free atmosphere, release the sensible heat, convert potential energy into kinetic energy and, at the same time, serve as a resevoir of water themselves. The optical observation of cloud which may be carried rather easily could be equivalent to many other observations in understanding the physical processes in the atmosphere if a certain synoptic and/or cloud physical informations are incorporated.

In the Japan Sea area, the air-sea interaction had been well studied by Miyazaki (1949), Manabe (1957, 1958) and Ninomiya (1964 a and b) especially for winter time situation because the prevailing north-westerly monsoon is greatly modified and brings quite a characteristic weather to the downstream regions. "Sea effect snowfall" in the windward side of the Japan Islands which sometimes causes a lot of damages is undoubtedly related to the moisture and heat supply from the sea surface. According to Jacobs (1951), the amount of supply is considered to be proportional to the air-sea temperature difference and, therefore, it has long been tried to correlate the amount of precipitation to the sea surface temperature of the Tsushima warm current.

As one item of the Heavy Snow Storm Project observations, we carried an aerial photographic survey on cloud distribution of wider area from high altitude (Heavy Snow Storm Research Group, 1965). A DC-8 jet plane was chartered for this purpose. Benifits of using such a high cost aircraft are not only in the high precision of steering and locationing required for aerial photographic analysis but also in its high speed at a high altitude, because of which wider area can be covered in shorter time. The flight was made on January 20, 1965, the last day of the IQSY observation interval during which 
worldwide aerological observations are available four times a day. 3-hourly aerological observation was also designed on the same date for smaller scale project observation network distributed in Hokuriku district, the central part of the Japan Sea coastal area.

\section{The methods of observation and analysis}

As shown in the project report (the Heavy Snow Storm Research Group, 1965), a series of high oblique photographs was taken from right and left side cabin windows of a DC- 8 jet plane at every $15 \mathrm{sec}$. The flight path is given in Fig. 1. The small circles along the path show the accuracy of positioning by means of Loran fix with the indication of Greenwich time. The altitude, the true air speed and the heading were kept constant for each of the straight courses. The altitude was $10710 \mathrm{~m}$ and the ground speed measured by Doppler radar ranged from 400 to $550 \mathrm{knot}$ (the wind at the flight level was $260^{\circ} / 80 \mathrm{knot}$ on the average) and therefore the vehicle advanced about $3.5 \mathrm{~km}$ from an exposure to the next.

About 440 photographs were thus taken on each side respectively and covered the total area of roughly $250,000 \mathrm{~km}^{2}$ which is about

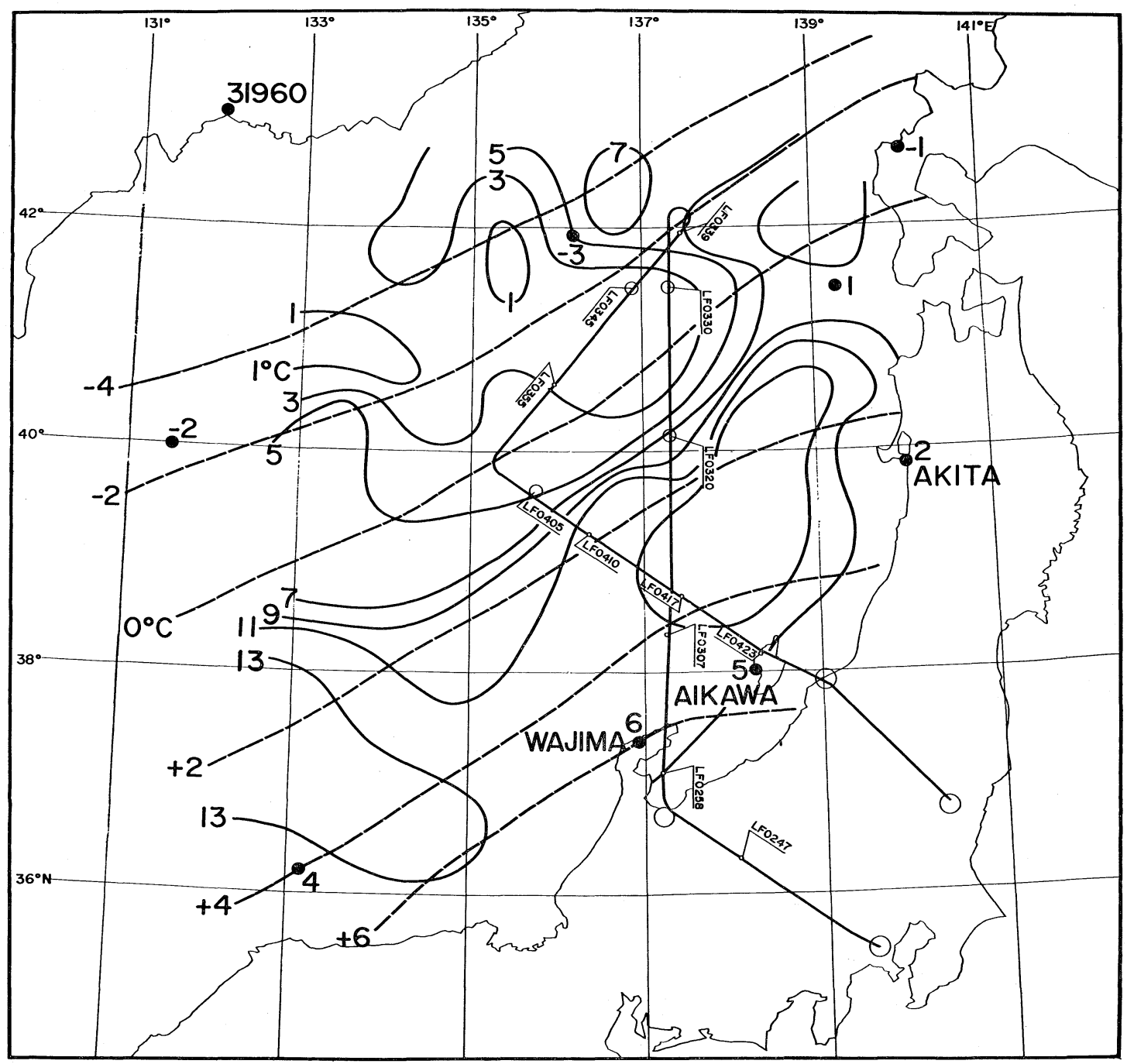

Fig. 1. The flight path, the surface air temperature (broken lines) and the surface sea temperature (solid lines). Small circles along the flight path shows the accuracy of locationing at the time of Loran fix labelled in Greenwich time. 
one fourth of the size of the Japan Sea since the lateral extent of analizable area on a single high oblique photograph is practically about $80 \mathrm{~km}$ from the subpoint if the cloud height is comparatively low.

Analyses were made on clouds as follows: Amount of cloud-At each of the exposure times, we considered square areas of $20 \mathrm{~km} \times$ $20 \mathrm{~km}$ on a horizontal plane at the average cloud height of $2 \mathrm{~km}$ above subpoint. (The perspective grid on the image plane is entered in Figs. $13 \mathrm{a} \sim$ e.) The amount of cloud is measured as a ratio of the cloud coverage to the whole area within each square area. Then a difficulty arises to the clouds in a farther distance because the thickness of cloud causes a serious error. Since the measurement is apt to be very subjective, we applied the scoring method of gymnastics by 4 umpires, i.e. taking the average of middle two scores. A verification of the validity of the obtained value can be made by taking into account the number and the representative size of clouds within the square area under consideration.

Cloud height-If we neglect the movement of cloud against the airplane movement, the stereoscopic principle is applicable to successive photographs on which the same object appears. Let us consider a square grid of $20 \mathrm{~km} \times 20 \mathrm{~km}$ on the plane tangential to the earth at the subexposure point $S .2$ or 3 cloudlets are selected in each of perspective square areas. Then we pursue the perspective projection $F$ of the object cloud $C$ onto the coordinate plane which moves with the airplane. The trajectory of the projection point appears as a straight line $F_{1} F_{2}$ on the

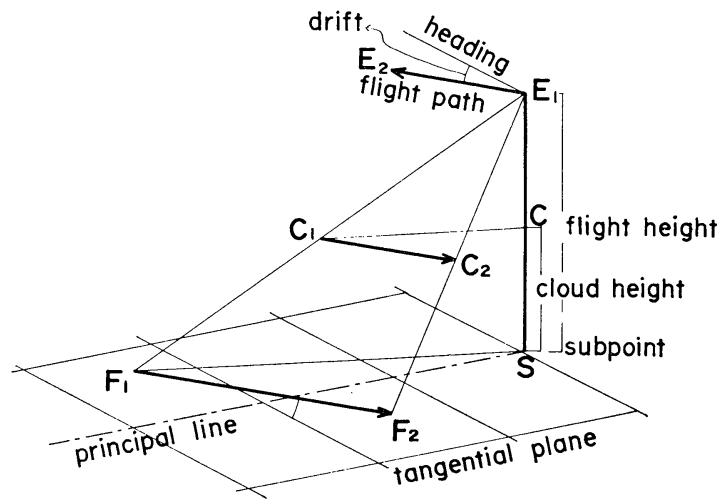

Fig. 2. Geometry of photogrammetry. moving coordinate with a certain angle which coincides approximately with the drift angle (see Fig. 2).

From a simple geometrical consideration it can be shown that the ratio of the displacement of a projected point $F_{1} F_{2}$ to that of the aircraft $E_{1} E_{2}\left(=C_{1} C_{2}\right)$ is equal to the ratio of the flight height $E_{1} S$ to the cloud height $C S$ if the earth's curvature is neglected. The correction of height due to the earth's curvature is then easily introduced.

If the shadow of a cloud is found on the sea surface, it is easy to estimate the cloud height by knowing the elevation of the sun. This method is also employed for a verification.

Other informations to characterise the convective activity such as the size and number of cloud within reference areas are also measured.

\section{Synoptic situations}

Our observation flight was executed from 0224 to $0459 \mathrm{Z}$ (1124 to 1359 LMT) on January 20, 1965. The surface weather chart at $03 \mathrm{Z}$ is given in Fig. 3. A cyclone is located off

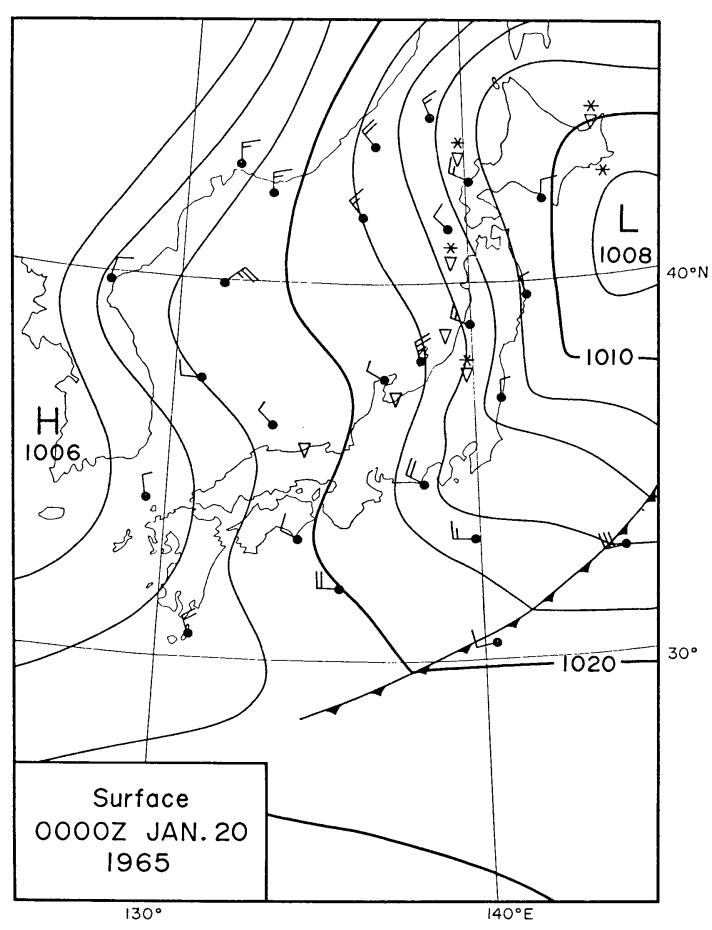

Fig. 3. The surface weather map at $00 Z$ January 20, 1965. 

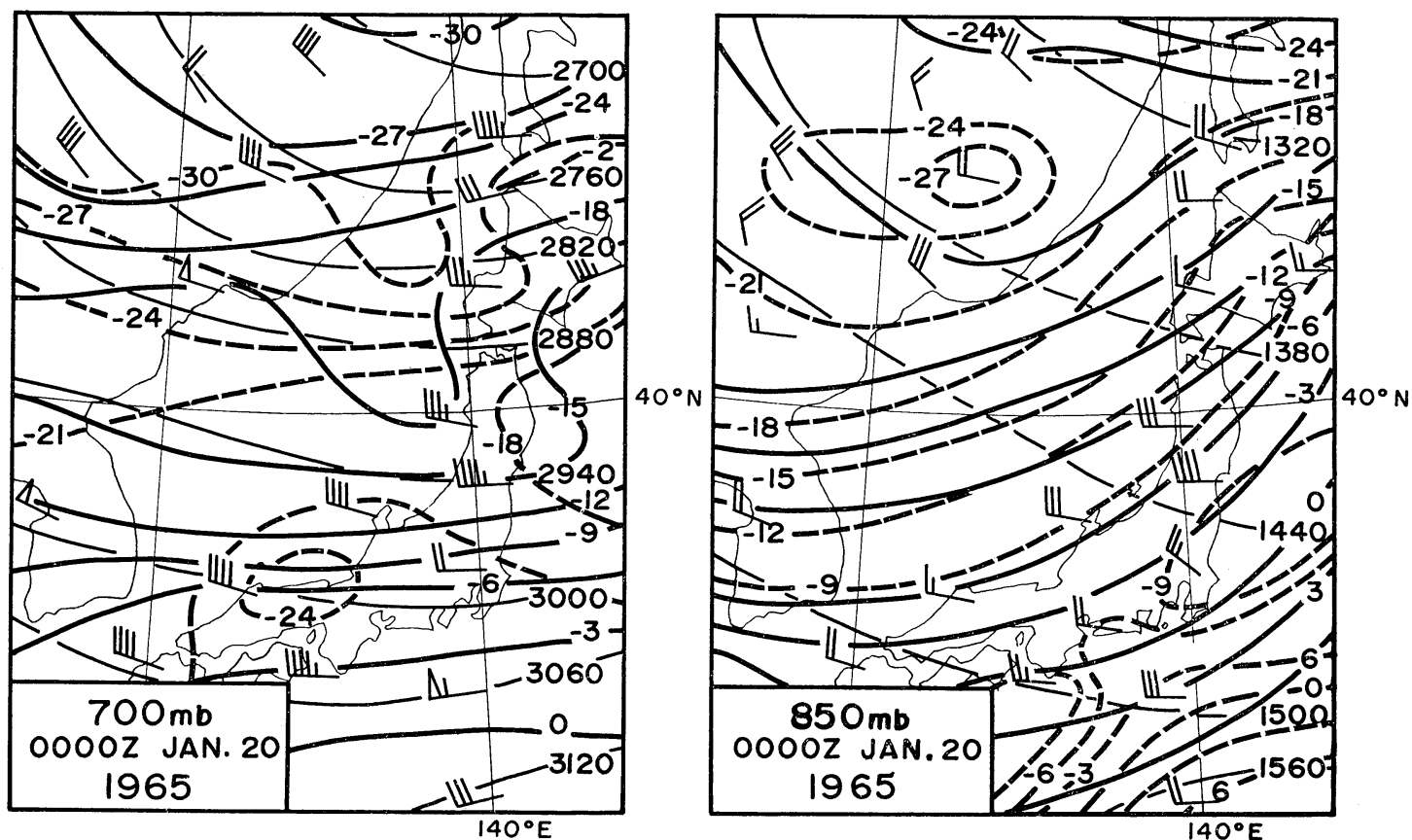

Fig. 4. The upper chart at $700 \mathrm{mb}$ level (left) and at $850 \mathrm{mb}$ level (right). Thinner full lines show geopotential height labelled in gmp, heavier full lines temperature labelled in ${ }^{\circ} \mathrm{C}$ and broken lines dew point temperature labelled in ${ }^{\circ} \mathrm{C}$ respectively. Full berbs indicate 10 knot.

the southeast coast of Hokkaido and rather weak northwesterly monsoon is observed over the Japan Sea. The monsoon type precipitation is observed here and there in the northern part of Japan. While in the upper atmosphere, a remarkably zonal westerly flow prevails over Japan at an unusually higher latitude. Fig. 4 shows $700 \mathrm{mb}$ and $850 \mathrm{mb}$ chart at $00 \mathrm{Z}$. Thinner solid lines show pressure height contours, heavier solid lines isotherms and dashed lines isolines of dewpoint temperature respectively. It is clearly seen over the Japan Sea region that the temperature advection and the water vapor advection amount considerably at $850 \mathrm{mb}$ level but they almost vanish at $700 \mathrm{mb}$ level as is usually observed on the winter time monsoon situation. Since the former is related to the horizontal heat transfer and the latter to the horizontal moisture transfer, this fact shows that the air mass modification over sea surface takes place principally within the lowermost layer of the atomosphere below $700 \mathrm{mb}$ level.

The stratifications at the monsoon upstream side of the Japan Sea and at the downstream are given altogether on Fig. 5. The ascent

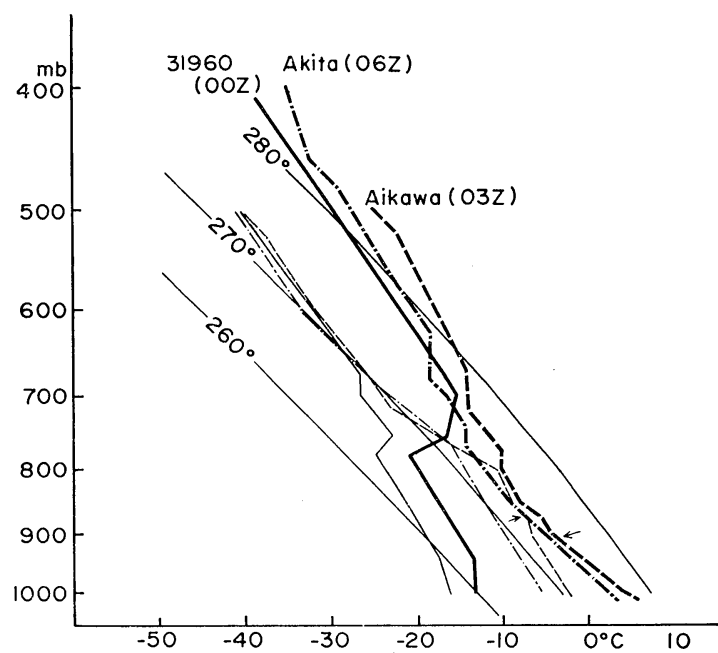

Fig. 5. The vertical distribution of temperature (heavier lines) and dew point temperature (thinner lines). The observation in 31960 at $00 \mathrm{Z}$ is shown by a pair of full lines, that in Aikawa at $03 Z$ by a pair of broken lines and that in Akita at $06 \mathrm{Z}$, January 1965 by a pair of chain lines respectively. Arrows indicate condensation levels. Moist adiabats are also entered by thin full lines labelled in ${ }^{\circ} \mathrm{K}$. 
curve at the upstream station 31960 (full line) is to be compared with that at the downstream station Aikawa (broken line) 3 hrs later or Akita (chain line) 6 hrs later (see Fig. 1 for the location of stations). A remarkable continental inversion and fairly stable air under it disappear while the air column travels over the Japan Sea. On her downstream side, a very unstable layer characterized by a dry adiabatic lapse rate near the surface and a wet adiabatic lapse rate in the upper part is observed, which undoubtedly shows an effect of predominant convective activity. The change in the vertical distribution of dewpoint temperature as shown by thinner lines in Fig. 5 suggests a characteristic feature of air mass modification, i.e. the redistribution of moisture supplied from the warmer sea surface is limited in the convective layer. Just above it, we can find a fairy stable layer in which the relative humidity drops discontinuously. The stratification seems to be quite similar to the situation concerning the trade inversion studied by Riehl and Malkus (1957).

In Fig. 5 is shown the condensation level by short arrows. Looking at the observation at Aikawa, we find that the condensation level is at $900 \mathrm{mb}$ and that both of the lapse rate and the humidity suddenly change at $800 \mathrm{mb}$. Therefore the cloud is expected to exist within the layer between $800 \mathrm{mb}$ and $900 \mathrm{mb}$, and actually it was the case.

The sea surface temperature distribution and air temperature distribution are given in Fig. 1. Since the sea surface temperature (solid lines) is considered to be more or less conservative, the observations within 5 days from January 18 to January 22 are entered to supplement the sparse observation. While the air temperature over sea (dashed lines) is obtained by the linear interpolation based upon ship observations and coastal observations indicated by black circles in the figure at $00 \mathrm{Z}$, January 20. A characteristic feature of the sea surface temperature over the Japan Sea is obviously the existence of the pretty warm "Tsushima Current" which is observed along the Japan Islands. Another remarkable fact revealed in Fig. 1 is that a considerably cold water mass appeared in the midst of the Japan Sea, which will be refer- red in the following sections with regards to the cloud distribution.

\section{Cloud distribution}

Summarizing the informations on cloud distribution over the Japan Sea under wintertime monsoon situation which have since been collected, the cloud generally starts to form at about hundreds $\mathrm{km}$ off the coast of the Siberian Continent and gradually increases its density toward Japan Islands associated sometimes with remarkable streakiness (see e.g. Asai, 1964).

Fig. 6 shows the cloud amount field observed from 12 to $13 \mathrm{LMT}$ (from 03 to $04 \mathrm{Z}$ ) by our project observation. The flight path with the indication of local time is given by a heavier solid line. Contour lines of cloud amount are discontinued over the superposed

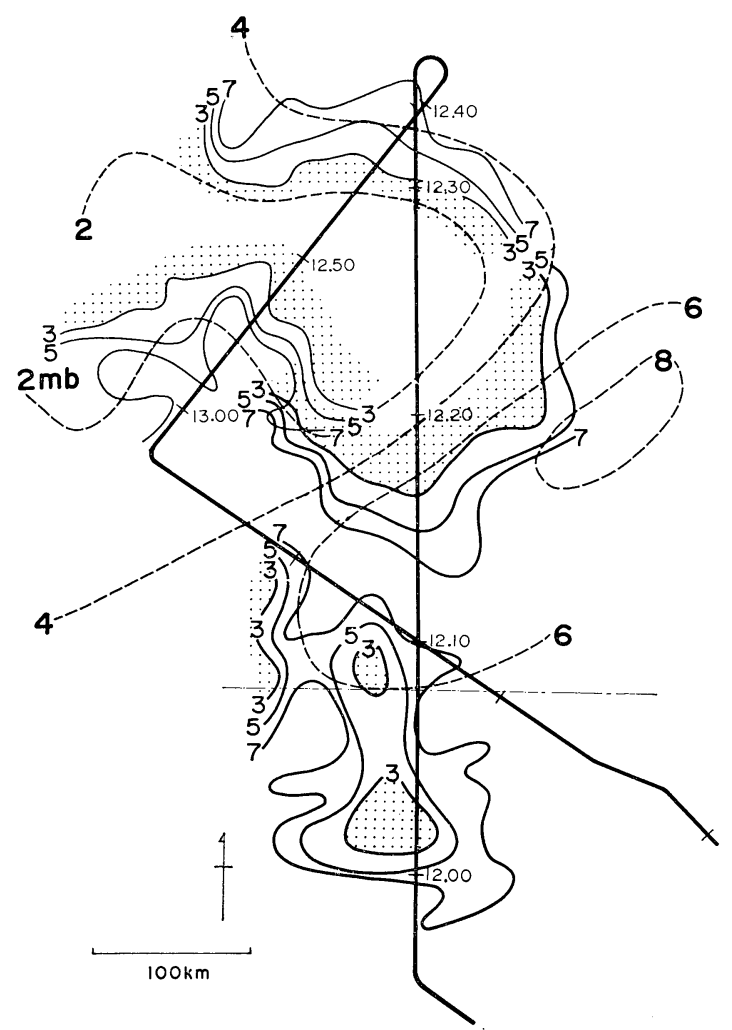

Fig. 6. Cloud amount distribution (thinner solid lines) in the neighbourhood of flight path (heavier solid line) observed from 12 to 13 LMT (from 03 to $04 \mathrm{Z}$ ). The areas of smaller cloud amount are stippled. The air-sea vapor pressure difference is also entered by broken lines labelled in every $2 \mathrm{mb}$. 
area because of the difference in observation time. The area with very small amount of cloud is indicated by stipples. It is pointed out that a large cloudless area of the size of $200 \mathrm{~km}$ is observed in the middle part of the Japan Sea, and that smaller cloudless areas are also found towards south.

On Fig. 6 are also shown the isolines of $e_{s}-e_{a}$ the difference between the saturation vapor pressure at the sea-surface temperature and that at the air temperature by dashed lines. The values are obtained from the airsea temperature field given in Fig. 1 by assuming that the air is saturated.

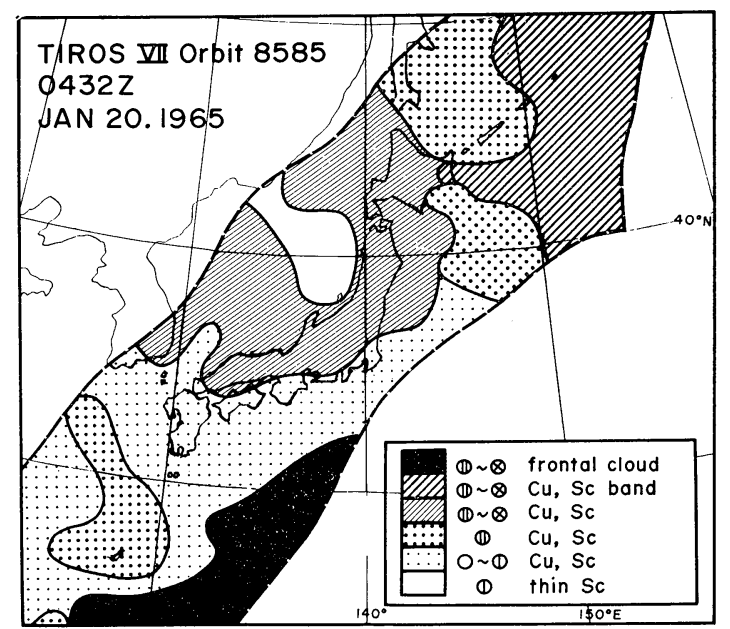

Fig. 7. Tiros VII observation over the Japan Sea area at $0432 \mathrm{Z}$ January 20, 1965.

The cloudless area is also detected by Tiros VII observation at $0432 \mathrm{Z}$ given in Fig. 7. The description of cloud form and the location may be said to represent the general feature which is obtained by our aerial observation. The cloud covers and types from synoptic reports at $00 \mathrm{Z}$ is presented on Fig. 8 for the sake of reference.

It is the most noticeable feature of cloud distribution that the cloudless area is observed in good agreement with the area of less air-sea temperature difference and therefore less air-sea vapor pressure difference. According to Jacob's (1951) empirical formula of evaporation $E=0.142 V\left(e_{s}-e_{a}\right)$ and the observation of wind by ship from the area under consideration, the amount of evaporation is estimated there to be less than $2 \mathrm{~mm} /$ day. While the moisture advection within

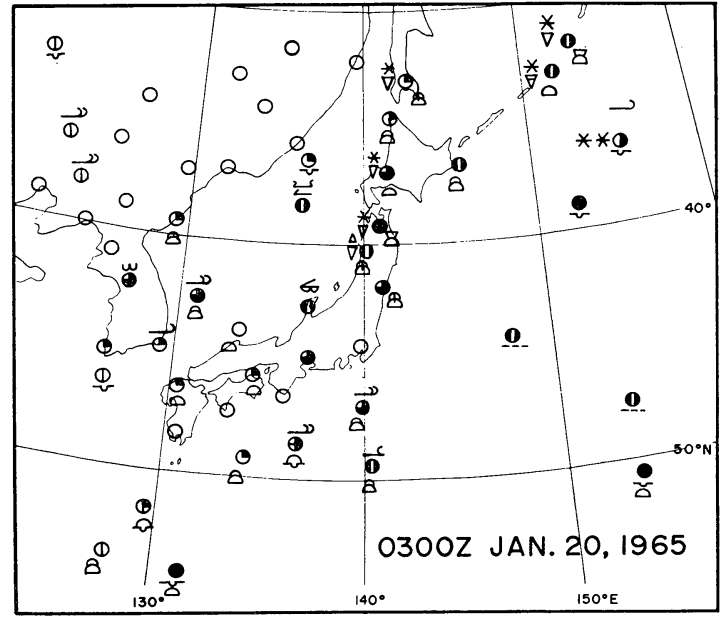

Fig. 8. The cloud observation by surface stations at $03 \mathrm{Z}$ January 20, 1965.

the layer below cloud is about the same amount, which will be discussed in the following.

Fig. 9 gives the similar picture as Fig. 6 for the cloud amount observed from 1305 to 1322 LMT on the way back. It covers the same area as observed about an hour earlier.

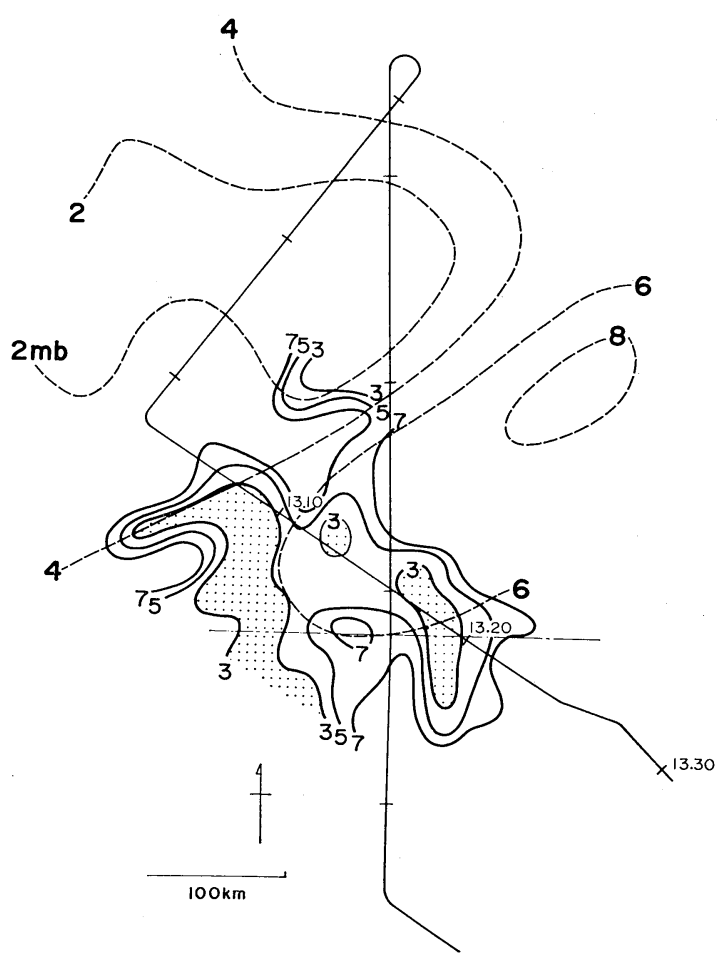

Fig. 9. The same as Fig. 6 for the period from 1305 to 1322 LMT (from 0405 to 0422 Z). 
Here again we find cloudless areas, but they are of much smaller sizes and are located over the considerably warmer sea surface. Comparing Figs. 6 and 9 we obtain Fig. 10

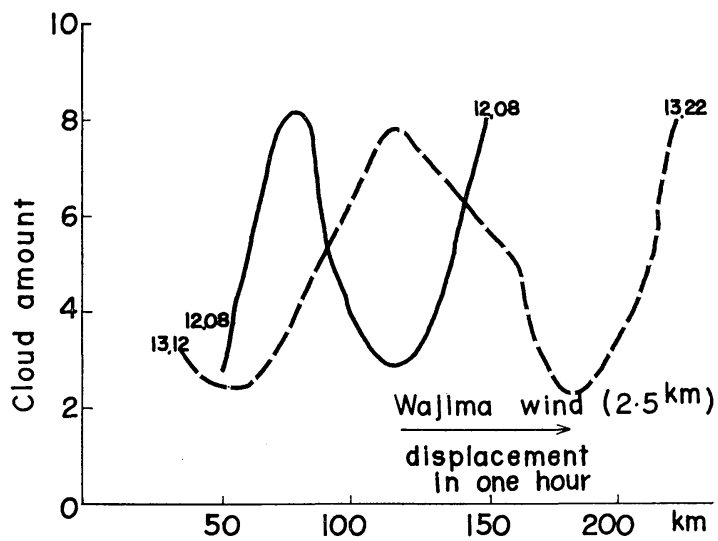

Fig. 10. Cloud amount distribution along the east-west line indicated by chain lines in Fig. 6 and 9. The numbers labeled on the curves are the time of observation.

which shows cloud amount along the same line indicated by chain lines in Figs. 6 and 9 . The times of observation are labeled. It is seen that the cloud amount field shows a meso-scale fluctuation (the wave length is about $150 \mathrm{~km}$ ) and eastward movement with a velocity of $70 \mathrm{~km} / \mathrm{hr}$ which is in good agreement with the wind at cloud level observed in Wajima at $03 \mathrm{Z}$.

The cloud height distribution is presented on Fig. 11 within the entire area of analysis. It shows up a quite similar pattern as the cloud amount field, indicating that the cloud hight is smaller in the area of smaller cloud amount. On account of this circumstance the height of individual clouds are classified by means of cloud amount and plotted in Fig. 12. The cloud form is divided into three categories, i.e. weak convective cumulus with a diameter less than $1 \mathrm{~km}$, organized convective cumulus with a diameter more than $1 \mathrm{~km}$ and stratified cloud as indicated by three symbols (see legend in the figure). It is pointed out that the lower limit of the cloud height which may be regarded as the cloud base is approximately $800 \mathrm{~m}$ and agrees with the condensation level at Aikawa as is seen in Fig. 5, and that the cloud height does not exceed $2200 \mathrm{~m}$ as is suggested also in the ascent curve at Aikawa mentioned before.

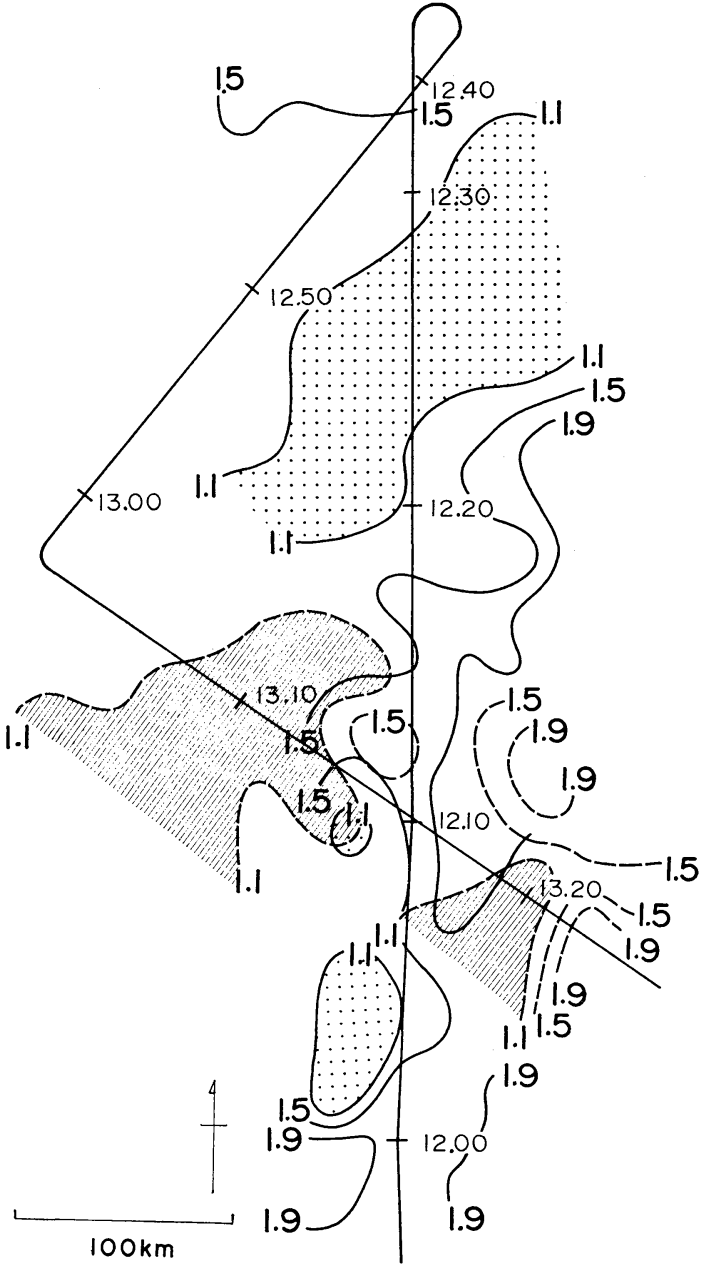

Fig. 11. Cloud height distribution labeled in $\mathrm{km}$ along the neighbourhood of flight path (heavier solid line). Observation on the way back is shown by broken lines.

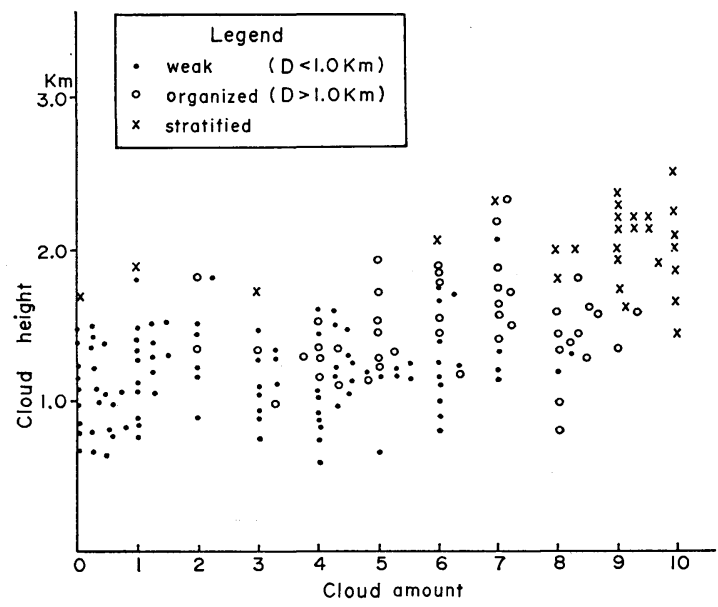

Fig. 12. The cloud height as a function of cloud amount. Clouds are classified into three categories as shown in the legend. 


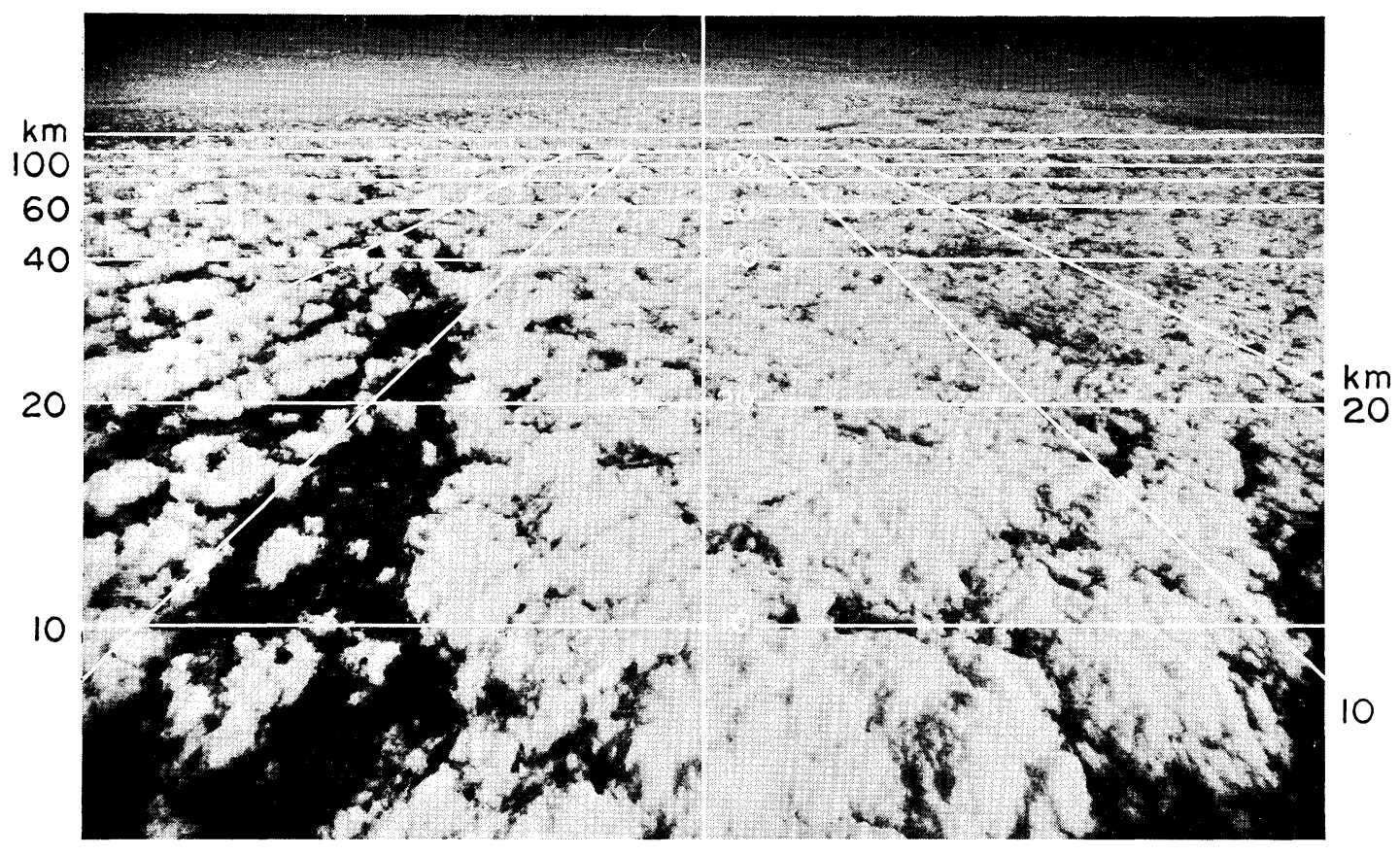

(a) 1212 LMT

0

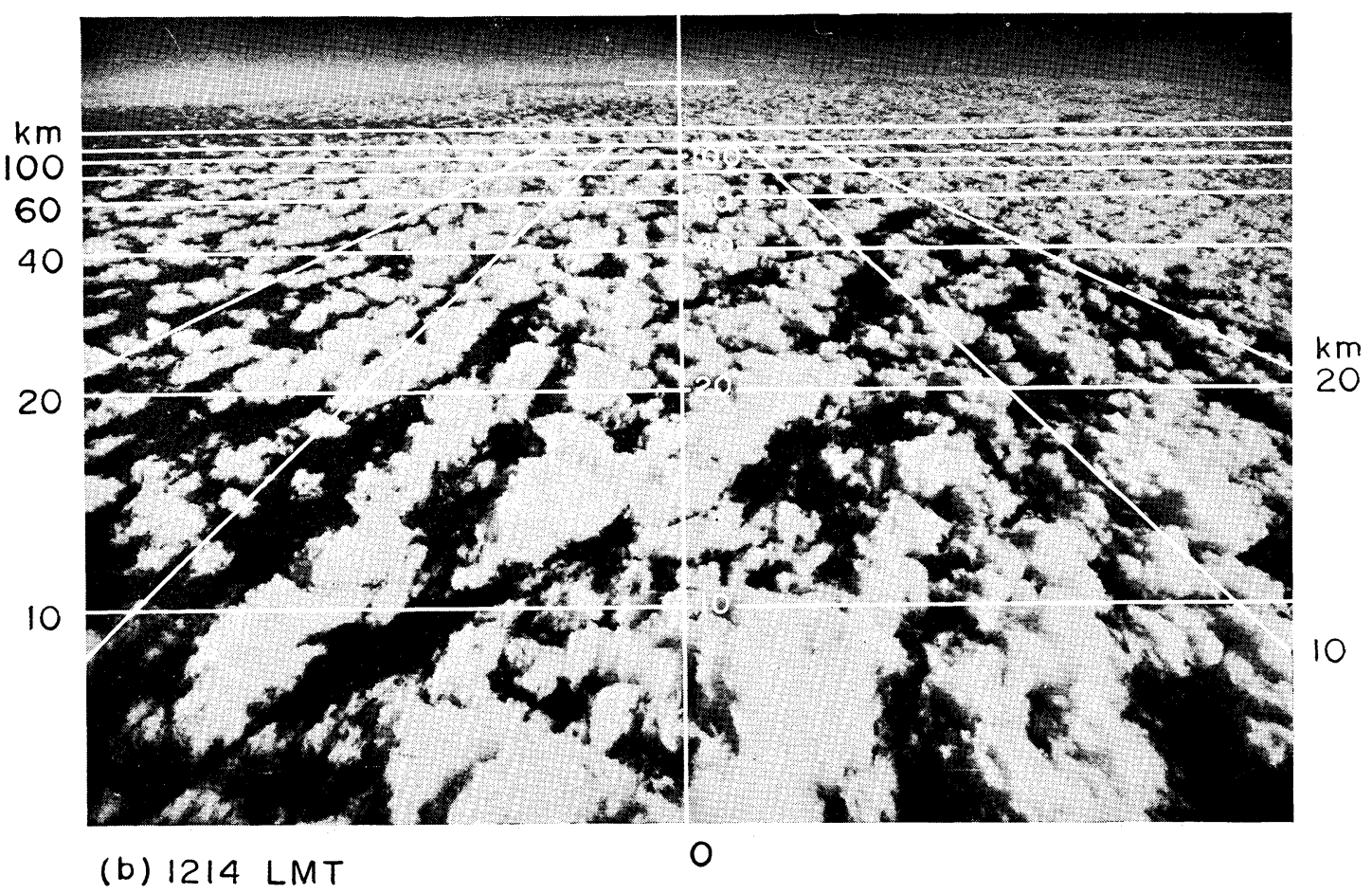




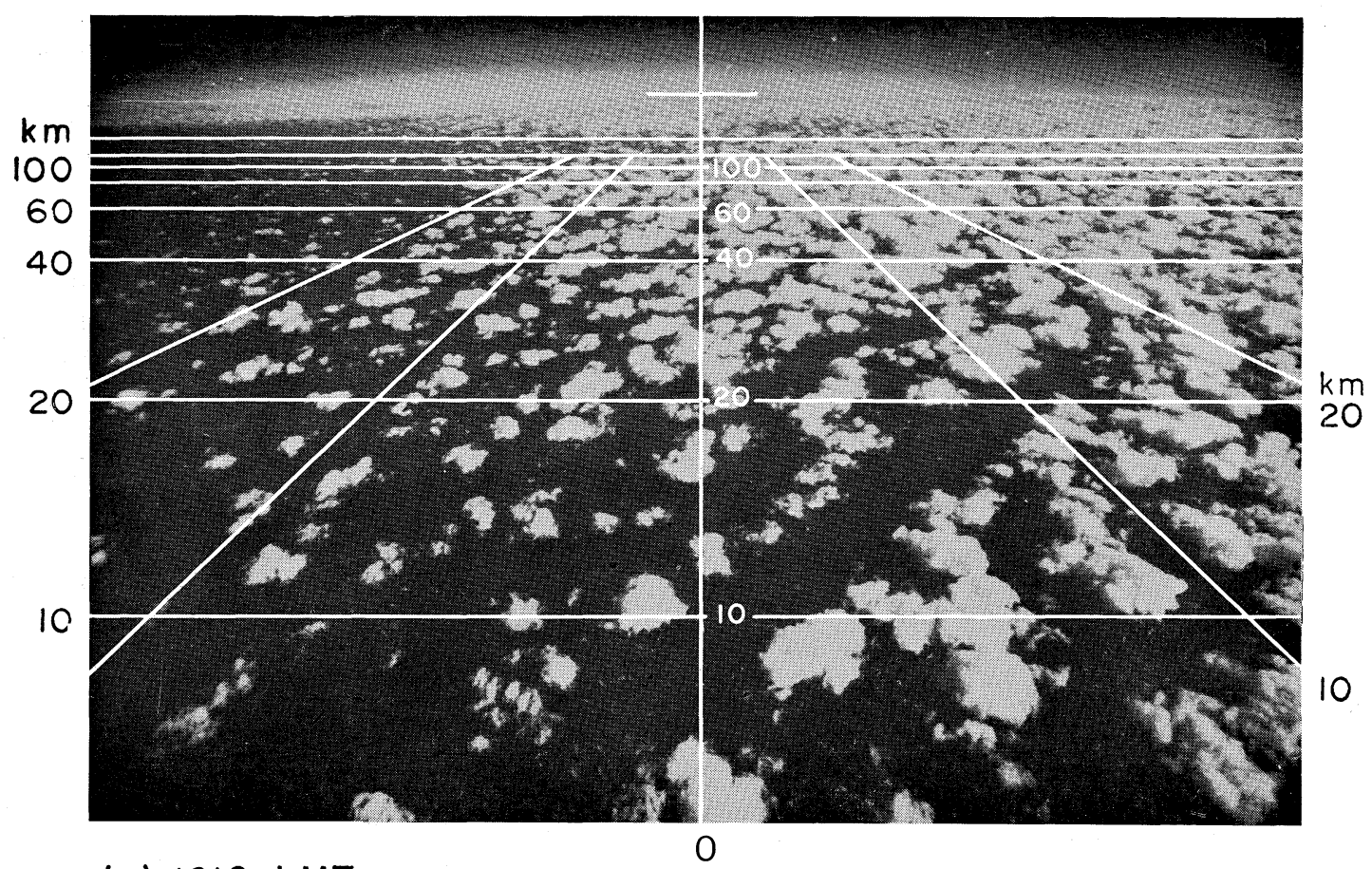

(c) 1216 LMT

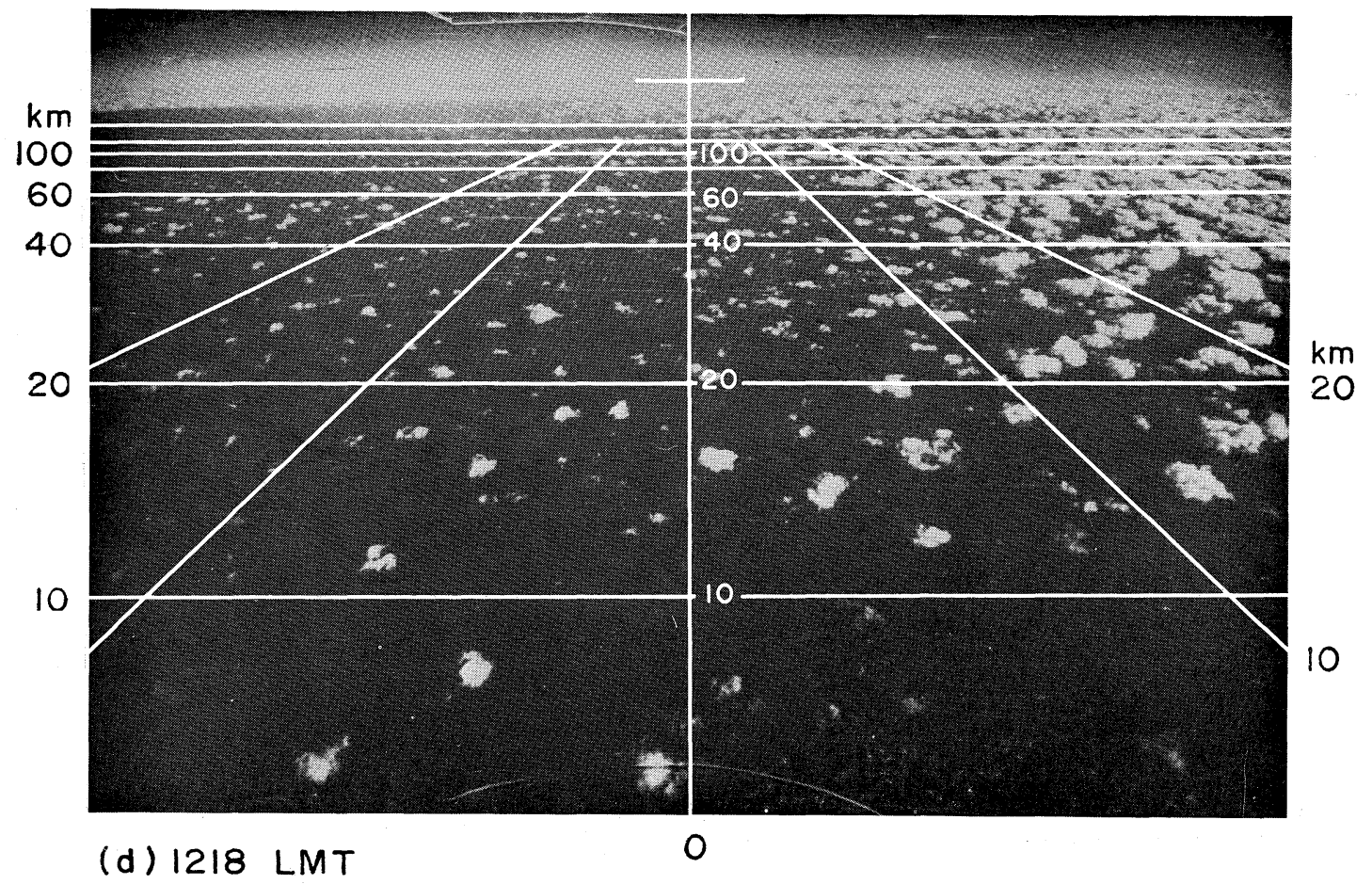




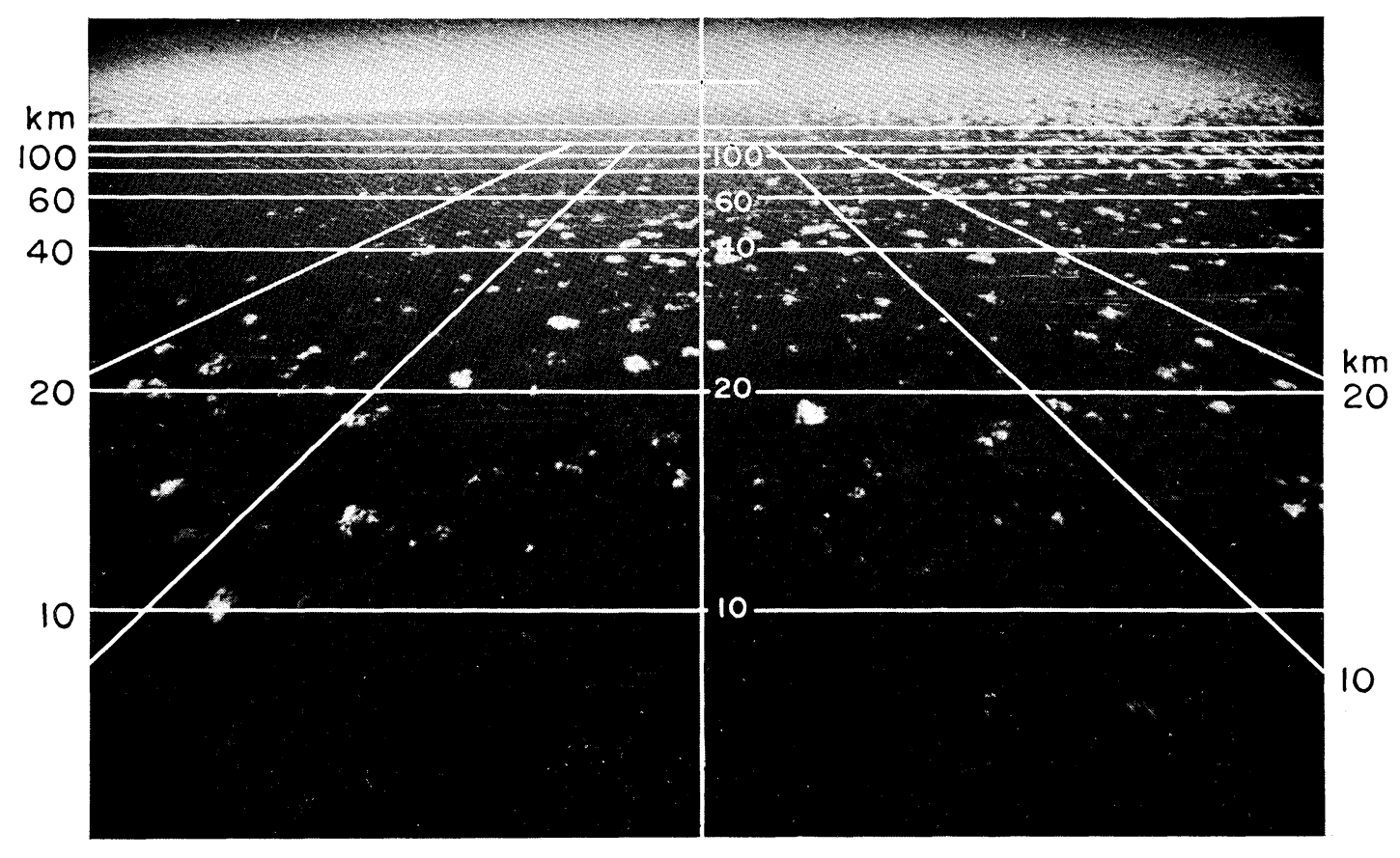

\section{(e) 1220 LMT}

Fig. 13. A series of high oblique photographs taken at (a) $1212 \mathrm{LMT}$, (b) $1214 \mathrm{LMT}$, (c) 1216 LMT, (d) 1218 LMT and (e) 1220 LMT January 20, 1965 respectively from the right hand side window. Perspective grids entered in each pictures are for the average cloud height $2 \mathrm{~km}$.

The averaged cloud height over the Japan Sea is thus estimated to be $1140 \mathrm{~m}, 1470 \mathrm{~m}$ and $1880 \mathrm{~m}$ for 99 weak convective cumuli, 49 organized convective cumuli and 46 stratiform clouds respectively. The absolute measurement of cloud height by means of shadow is made on selected 76 cloudlets to verify the method mentioned above by which the stereoscopic principle is applied on a series of successive photographs. It gives the average of $1080 \mathrm{~m}$ showing a good agreement since shadow method is applicable only for smaller clouds.

\section{Detailed analyses on cloud formation over the Tsushima warm current}

The concentration of contour lines of sea surface temperature indicates the existence of warm current where a predominant vapor supply is expected. Across the transitional zone, the cloud distribution shows quite a characteristic field. Fig. 13 presents a series of the right hand side photographs for every 2 min from 1212 to 1220 LMT. There can be seen the marked transition from scattered very small convective clouds to stratiform clouds which look just like Benard's cell type convection. Detailed analyses are made on the cloud field observed from 1212 to 1221 LMT covering approximately $120 \mathrm{~km}$ along the flight path.

Measurements are made on the cloud amount $\sigma_{c} / \sigma_{0}$ which is the ratio of the cloud covered area to the total area, the representative diameter of cloud, $D$, the number of clouds within the total area of $10 \mathrm{~km} \times 20 \mathrm{~km}$ $N$, the cloud height $h$ and the equivalent thickness of cloud as a measure of total mass of cloud. Fig. 14 shows those quantities as a function of the observation time. On the top of this figure is presented also the amount of evaporation $E_{s}$ estimated by Jacob's formula mentioned above assuming that the air is saturated.

It should be noted that the number of cloud seems to be almost constant regardless to the size of cloud. It is probably related to the uniformity of the size of convection ele- 

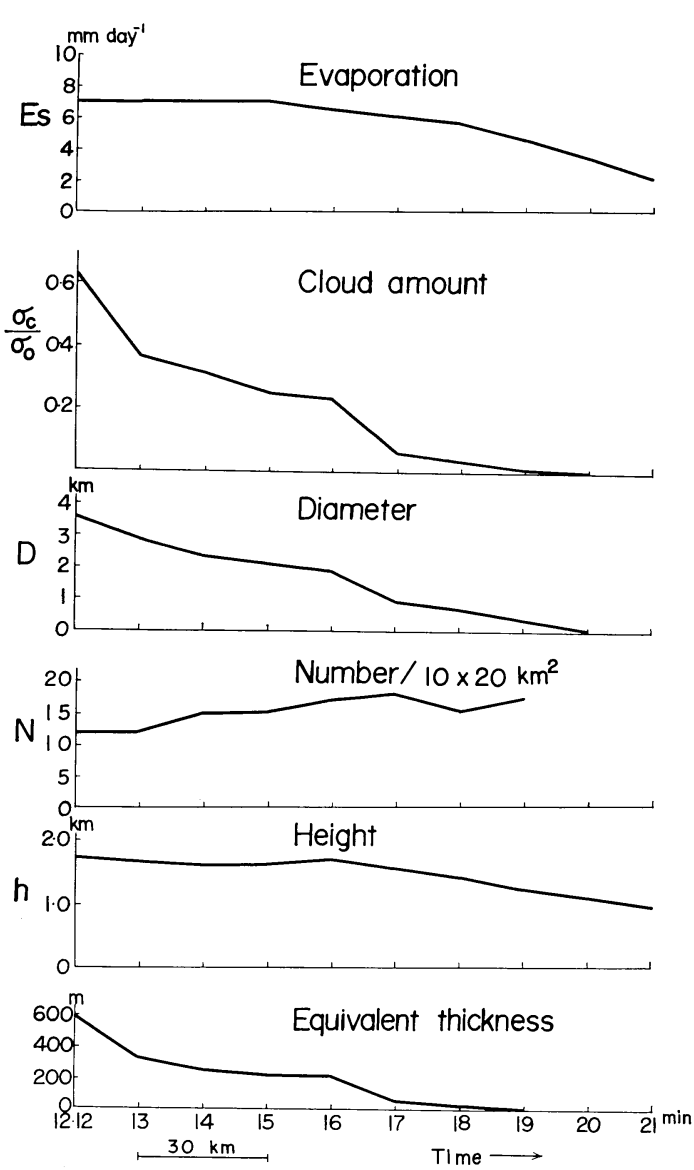

Fig. 14. Distribution of cloud characteristics along the flight path from south to north. The abscissa is the time and the distance is given at the bottom. From top to bottom are shown the evaporation from the sea surface, the cloud amount, the diameter of cloud, the number of cloud within the area of $10 \mathrm{~km} \times 20 \mathrm{~km}$, the cloud height and the total volume of cloud expressed in equivalent thickness respectively.

ment. Since the averaged number is 15 , the convection element is found to occupy the area of $13.3 \mathrm{~km}^{2}$ and, therefore, the diameter of the representative convection cell is estimated to be $4.1 \mathrm{~km}$ which is roughly the size of Benard's cell observed at 1212 LMT. Considering the height of cloud or that of inversion the ratio of horizontal to vertical dimension is found to be about 2.0.

Asai (1964) obtained the ratio of 2.0 for moderate cumulus convection of about $1 \mathrm{~km}$ height. While the authors (1965) showed another example of very active convection over the Japan Sea accompanied by heavy snowfall, and obtained nearly the same ratio of 2.0 for much larger convection system having $11.7 \mathrm{~km}$ of convection cell diameter and $107.5 \mathrm{~km}^{2}$ of covering area. According to the theory of Jeffreys (1928), the ratio of the wave length to the thickness of the convective disturbance is likely to be 2.8 . The observed values given above show good agreements.

The cloud amount $\sigma_{c} / \sigma_{0}$ increases rapidly towards downstream warm current region. Assuming a uniform height of cloud base we can estimate total volume of cloud mass from the information on cloud amount and cloud height. Thus we obtain the equivalent thickness of cloud as shown at the bottom of Fig. 13. It can be seen that considerable amount of condensed water production is required to maintain the cloud mass advection. Further discussions will be made in the next section.

\section{Some experimental budget analyses on air mass modification under steady state assumption}

Basing on the materials given above, let us try to make some water and heat budget computation on this particular situation. It is convenient to divide the lower atmosphere into 3 layers, subcloud layer, cloud layer and above cloud layer respectively. As seen in the previous sections, it may be considered that there is no appreciable modification above $700 \mathrm{mb}$ and that clouds are observed within the layer between $800 \mathrm{~m}$ and $2,000 \mathrm{~m}$.

Now let us confine our attention to the area of $120 \mathrm{~km}$ in north south direction where we observed a characteristic arrangement of cloud and a significant gradient of sea surface temperature. Using the observation at surface, $850 \mathrm{mb}$ and $700 \mathrm{mb}$ at $00 \mathrm{Z}$ January 20 , 1965 (given in Figs. 3 and 4) we can easily estimate the horizontal large scale advection of vapor (latent heat) and sensible heat. We can also estimate the condensed water advection from the information obtained by jet plane observation of cloud distribution if the water content in clouds is known. Ignoring the time changes or time difference in observation, we obtain heat and water budget 
in the area under consideration.

The horizontal advections by large scale motion are computed on each map levels and linear distribution is assumed in between. Thus we obtain the magnitude of advective terms for each of 3 layers.

In discussing the water budget in winter, the advection of condensed water is as significant as that of vapor since the vapor content is very small because of low temperature. Ninomiya (1964 a) showed that the flux divergence of condensed water is about $43 \%$ of that of vapor over the Japan Sea in his analysis on a period of heavy snowfall. As is shown on the bottom of Fig. 14, there is a gradient of total cloud volume (equivalent thickness) indicating the existence of cloud particle advection. Applying the Ackerman's (1959) empirical formula of relative water content to our situation, we find that the reasonable value of condensed water content in cumuli is $0.3 \mathrm{gr} \cdot \mathrm{kgr}^{-1}$. Thus the estimated value of the cloud particle advection is $0.6 \mathrm{~mm}$ day $^{-1}$ which amounts to $26 \%$ of the vapor advection. Comparing with the Ninomiya's result (1964 a) obtained by residual method, this value is somewhat smaller and is probably due to the difference in convective activity.

In discussing the budget of latent heat and sensible heat under steady state assumption, we have the following sets of equations for each of the 3 layers. The quation of vapor:-

$\left\{\begin{array}{l}\int_{2,000}^{3,000} \nabla V L q d z-(w L q)_{2,000}=0, \\ \int_{800}^{2,000} \nabla V L q d z+(w L q)_{2,000}-(w L q)_{800}=-C, \\ \int_{0}^{800} \nabla V L q d z+(w L q)_{800}=E_{s}+P_{1} .\end{array}\right.$

The equation of condensed water:-

$$
\left\{\begin{array}{l}
\int_{2,000}^{3,000} \nabla V \operatorname{Lm} d z=0 \\
\int_{800}^{2,000} \nabla V \operatorname{Lm} d z=C-P_{1}-P_{2} \\
\int_{0}^{800} \nabla V L m d z=0
\end{array}\right.
$$

The equation of sensible heat:-

$$
\left\{\begin{array}{r}
\int_{2,000}^{3,000} \nabla V c_{p} T d z-\left(w c_{p} T\right)_{2,000} \\
-\int_{2,000}^{3,000} \omega \alpha d z=0 \\
\int_{800}^{2,000} \nabla V c_{p} T d z+\left(w c_{p} T\right)_{2,000}-\left(w c_{p} T\right)_{800}- \\
-\int_{800}^{2,000} \omega \alpha d z=C \\
\int_{0}^{800} \nabla V c_{p} T d z \quad-\int_{0}^{800} \omega \alpha d z=Q_{s}-P_{1}
\end{array}\right.
$$

$L$ is the heat of vaporization, $q$ the specific humidity, $m$ the condensed water content, $c_{p}$ the specific heat under constant pressure, $E_{s}$ the latent heat transfer (evaporation) from sea surface, $Q_{s}$ the heating from the sea surface respectively. $C$ the condensation within the cloud layer, $P_{1}$ a part of the precipitation which evaporated in the subcloud layer and $P_{2}$ the precipitation which goes back to the sea surface are expressed in dimension of heating, and the density facter in each of transport terms is not written explicitly for the sake of simplicity. Here the flux form is adopted for the sake of convenience. It may be shown that the divergence of horizontal flux by large scale motion is approximately equal to the horizontal advection. The vertical flux term is principally contributed by convective transport. The energy conversion term, $\omega \alpha$, on the other hand, is mostly originated from large scale motion if any and the magnitude of $\omega \alpha$ caused by convection is rather a small fraction of convectional flux divergence in each of subdivided layers.

Combining the equations given above we obtain the following equations,

$$
E_{s}-P_{2}=\int_{0}^{3,000} \nabla V L(q+m) d z
$$

which shows the conservation of water substance and

$$
E_{s}+Q_{s}=\int_{=0}^{3,000} \nabla \boldsymbol{V}\left(L q+c_{p} T\right) d z-\int_{0}^{3,000} \omega \alpha d z .
$$

The known parameters appearing in the above equations are, first of all, the flux divergence terms which are obtained by horizontal distribution and temperature, dew 
point temperature and wind or pressure height. Thus we obtain

$$
\begin{aligned}
& \int_{2,000}^{3,000} \nabla \boldsymbol{V} L q d z=36 \\
& \int_{800}^{2,000} \nabla \boldsymbol{V} L q d z=138 \\
& \int_{0}^{800} \nabla \boldsymbol{V} L q d z=144 \\
& \int_{2,000}^{3,000} \nabla \boldsymbol{V} L m d z=0 \\
& \int_{800}^{2,000} \nabla V L m d z=36 \\
& \int_{0}^{800} \nabla \boldsymbol{V} L m d z=0 \\
& \int_{2,000}^{3,000} \nabla \boldsymbol{V} c_{p} T d z=55 \\
& \int_{800}^{2,000} \nabla \boldsymbol{V} c_{p} T d z=265 \\
& \int_{0}^{800} \nabla \boldsymbol{V} c_{p} T d z=200 .
\end{aligned}
$$

The units are all expressed in $1 \mathrm{y} d a y^{-1}$ and the evaporation or precipitation unit $\mathrm{mm}$ day $^{-1}$ is equivalent to $60 \mathrm{ly}$ day $^{-1}$.

Now the sensible and latent heat supply from the sea surface are given by Jacobs formulae (1951)

$$
\begin{aligned}
& Q_{s}=5.5 \times V\left(T_{s}-T_{a}\right), \\
& E_{s}=8.5 \times V\left(e_{s}-e_{a}\right),
\end{aligned}
$$

both in $1 y$ day $^{-1}$ unit. $V$ is the surface wind velocity in $\mathrm{m} \mathrm{sec}-1, T_{s}-T_{a}$ the temperature difference between sea and air in ${ }^{\circ} \mathrm{C}$ and $e_{s}-e_{a}$ the vapor pressure difference in $\mathrm{mb}$. From the temperature distribution presented in Fig. 1, we obtain

$$
Q_{s}=385 \text {. }
$$

This value is considerably smaller than Manabe's (1957) and Ninomiya's (1964 b) which are obtained under either predominant monsoon situation or heavy snowfall situation. The value of $E_{s}$, on the other hand, is more or less arbitrary since the relative humidity is not known. Considering that the total out flux of sensible and latent heat is $838 \mathrm{ln}$ day $^{-1}$ and assuming that the potential energy supply of $41 \ln d^{2} y^{-1}$ is expected due to a large scale downward motion of the order of $1 / 4 \mathrm{mb} / \mathrm{hr}$ accompanied by southward cold air outburst, the estimated value of $E_{s}$ becomes 412 ln day ${ }^{-1}\left(6.9 \mathrm{~mm} \mathrm{day}^{-1}\right)$ by eq. (5). The kinetic energy release due to convective activity is not considered here but will be referred to later.

It can be shown from eq. (4) that a certain amount of precipitation is required because the out flux of water substance amounts to $354 \mathrm{ly} \mathrm{day}^{-1}\left(5.9 \mathrm{~mm} \mathrm{day}{ }^{-1}\right)$ which is smaller than $E_{s}$ as mentioned above. Thus the estimated value of precipitation falling onto the sea surface

$$
P_{2}=59
$$

which is equivalent to $1.0 \mathrm{~mm}$ day $^{-1}$.

Finally the estimate of $P_{1}$, the evaporated precipitation in the subcloud layer, is quite arbitrary. We conventionally assume that $P_{1}$ is $10 \%$ of $P_{2}$ referring to the case of thundrstorm shower (Fujita, 1959), and we obtain

$$
P_{1}=6 \text {. }
$$

Now we can compute the condensation in the cloud layer $C$ from eq. (2)

$$
C=100
$$

which is equivalent to $1.7 \mathrm{~mm} \mathrm{day}^{-1}$.

The convective transfers after all are to be decided from eqs. (1) and (3) as follows

$$
\begin{aligned}
& (w L q)_{800}=274, \\
& (w L q)_{2,000}=36,
\end{aligned}
$$

and

$$
\begin{aligned}
& \left(w c_{p} T\right)_{800}=185, \\
& \left(w c_{p} T\right)_{2,000}=35 .
\end{aligned}
$$

Now we can estimate the kinetic energy production by cumulus convection indirectly from the values of vertical heat transfer given above. The integrated value of $\omega \alpha$ term within the cloud layer turns out to be

$$
R / c_{p} \cdot \Delta p / p \cdot\left\{\left(w c_{p} T\right)_{800}+\left(w c_{p} T\right)_{2,000}\right\} / 2
$$

where $\Delta p$ is the pressure thickness of the layer. Since the factor $R / c_{p} \cdot \Delta p / p$ is very small (0.04), we have neglegibly small amount of energy conversion compared to the vertical 
energy transport by convection. Although there is no doubt in that the kinetic energy release due to convective towers plays an important role for the maintenance of Hurricanes (Malkus, Ronne and Chaffee, 1961) or general circulation in general, our present situation primarily concerns with air mass modification by which the potential energy accumulation is of more importance rather than the kinetic energy release.

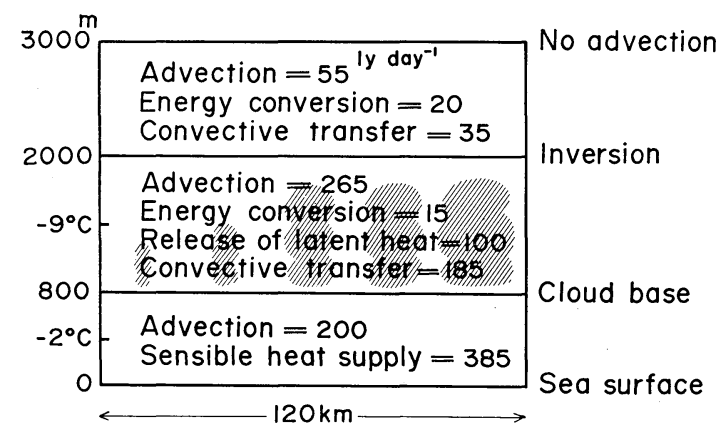

Schematic diagrams in Fig. 15 summarize the heat budget (left figure) and the water budget (right figure) obtained above. We can point out a couple of interesting facts concerning water substance transport.

The fact that the flux divergence of vapor amounts as much as $2.4 \mathrm{~mm}$ day $^{-1}$ within the subcloud layer might have a significant bearing with the observational fact that the cloudless area coincides with the area of

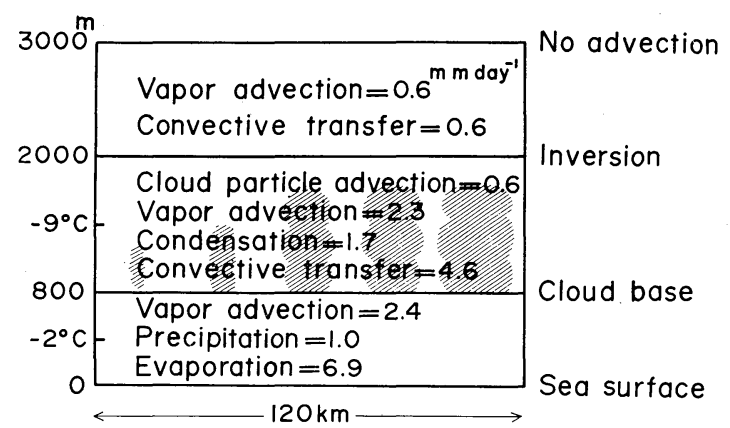

Fig. 15. Schematic diagram showing heat budget (left, in ly day ${ }^{-1}$ unit) and water budget (right, in $\mathrm{mm} \mathrm{day}^{-1}$ unit).

evaporation less than $2 \mathrm{~mm}$ day $^{-1}$. It provides an unfavorable condition for the cloud formation, since the evaporated water is removed out of the area under consideration in a form of vapor.

The surplus of evaporation is transported into cloud layer principally by convective activity. Thus the convective transfer $F$ through the level of cloud base is estimated to be $4.6 \mathrm{~mm} \mathrm{day}^{-1}$. The convective vertical velocity $w_{c}$ is related to $F$ as follows

$$
w_{c}=\frac{F}{\rho \sigma_{c} / \sigma_{0} \cdot\left(q_{c}-q_{f}\right)}
$$

where $\rho$ is the density, $q_{c}$ and $q_{f}$ the specific humidity in and out of the cloud respectively and $\sigma_{c} / \sigma_{0}$ the ratio of cloud cover. Averaging the value of $\sigma_{c} / \sigma_{0}$ over. the area under question (see Fig. 14) we obtain 0.23 as a representative value of $\sigma_{c} / \sigma_{0}$. As to the excess water $q_{c}-q_{f}$ of the cloud, we can refer to the 3 hourly aerological observations made at Wajima on the same day showing that the relative humidity difference between inside and outside of clouds seems to be about $20 \%$. Therefore it may be reasonable to apply the value of the order of $0.4 \mathrm{gr} \cdot \mathrm{kgr}^{-1}$ for $q_{c}-q_{f}$. Then we obtain a representative value of convective vertical velocity $0.5 \mathrm{~m}$ $\mathrm{sec}^{-1}$ at cloud base level. This value may be considerably smaller compared to the observed values in well developed cumuli probably because it was under a weak monsoon situation.

It should be pointed out concerning the relationship in vertical transfer of heat that the ratio of sensible heat transfer to latent heat transfer at the cloud base level is 0.68 and is considerably smaller than the Bowen's ratio $Q_{s} / E_{s}=0.93$. This is a general tendency often observed over the Japan Sea. It is suggested that the temperature contrast between up current (cloud) region and down current (non cloud) region diminishes in higher elevations because of adiabatic cooling of lifted air parcels, while the specific humidity contrast does not since the specific humidity is a more conservative quantity in the ascending air mass.

\section{Remarks}

During winter time the Japan Sea is undoubtedly playing a very important role on air mass modification and heavy snowfall 
downstream. It has long been interested in what is happening over the sea. Although the Japan Sea provides a natural laboratory in studying the air-sea interaction, the available observation has been quite sparse especially over sea. The recent development in the artificial sattelite observation is revealing some interesting features in cloud distribution.

The cloud distribution is closely related to the air mass modification. The cumulus convection contributes to redistribute the heat and water, to release the kinetic energy and to store the condensed water which might be precipitated out in heavy snow storm.

Analysing the materials of an aerial photographic observation made over the Japan Sea, we can obtain a couple of interesting informations. However the quantitative estimations tried here have to be based on assumptions. In order to make discussions more decisively, we have to observe cloud physical parameters such as the vertical motion, the water content in clouds, precipitation onto the sea and so on.

\section{Acknowledgments}

The authors express their thanks to Dr. K. Takahashi for his encouragement to the members of the Heavy Snow Storm Research Group for discussing, planning and participating in the observation flight. Thanks are also due to Mr. T. Yokozeki who cooperated with the authors for performing the charter flight, Mr. M. Okuyama who analysed numerous aerophotographs and Miss H. Imai who drafted the figures.

\section{References}

Ackerman, B., 1959: The variability of the water contents of tropical cumuli. J. Meteor., 16, 191-198.

Asai, T., 1964: Photographic observation of clouds by aircraft during snowfall period in Hokuriku
District. J. meteor. Soc. Japan, Ser. II, 42, 186196.

Fujita, T., 1959: Precipitation and cold air production in mesoscale thunderstorm systems. $J$. Meteor., 16, 454-466.

as revealed by photogrammetric analysis. Tech. Rep. No. 3, Univ. of Chicago, 9pp.

The Heavy Snow Storm Research Group, 1965: An aerophotographic observation of cloud over Japan Sea by a DC-8 jet plane. Tenki, 12, 236240 .

Jacobs, W.C., 1951 : Large-scale aspects of energy transformations over the oceans. Compendium of Meteorology, Amer. Met. Soc., 1057-1070.

Jeffreys, H., 1928: Some cases of instability in fluid motion. Proc. Roy. Soc., 118, 195-208.

Malkus, J.S., C. Ronne and M. Chaffee, 1961: Cloud patterns in hurricane Daisy 1958. Tellus, 13, 8-30.

Manabe, S., 1957: On the modification of air mass over Japan Sea when the outburst of cold air predominates. J. meteor. Soc. Japan, Ser. II, 35, 311-326.

- , 1958: On the estimation of energy exchange between the Japan Sea and the atmosphere during winter based upon the energy budget of both atmosphere and sea. J. meteor. Soc. Japan, Ser. II, 36, 123-134.

Matsumoto, S. and K. Ninomiya, 1965: An aerophotographic observation of convective clouds in the vicinity of a cold dome center. J. meteor. Soc. Japan, Ser. II, 43, 218-230.

Miyazaki, M., 1949: The incoming and outgoing heat at the sea surface along the Tsushima warm current. Ocean. Mag., 1, 103-111.

Ninomiya, K., 1964 a: Water-substance budget over the Japan Sea and the Japan Islands during the period of heavy snow storm. J. meteor. Soc. Japan, Ser. II, 42, 317-329.

, $1964 \mathrm{~b}$ : Heat budget over the Japan Sea and the Japan Islands during the period of heavy snow storm. Papers in meteor. and Geophys., 15, 52-70.

Riehl, H. and J.S. Malkus, 1957: On the heat balance and maintenance of circulation in the trades. Quart. J. Roy. meteor. Soc., 83, 21-29. and 1958 : On the heat balance in the equatorial trough zone. Geophysica, 6, 503-538. 


\title{
冬期弱い季節風下における日本海々上の雲の発生および その熱・水蒸気補給との関連について
}

\author{
松 本 誠一・宮 洸 三
}

気像研究所

1965 年 1 月 20 日, 日本海で高々度よりの雲の航空写真観測を実施した。当日は比較的弱い季節風下にあった。注 目すべき事実は, 雲量分布が表面水温分布と密接関連していたこと, 雲高は殆んど一様飞約 $2 \mathrm{~km}$ と推定され, 高 層観測飞よる逆転層の底面の高さとよく一致していたこと, 拉よび対流系の大ささが雲の大きされかかわらずほぼ一 定であったことなどである。

雲の全容積の観測值を用いると凝結した水の収支を定常状態の仮定の下飞計算することができる。周囲の観測から できる熱と水蒸気の収支計算をこれにより改善することができた。 